\title{
What is a reindeer? Indigenous perspectives from northeast Siberia
}

Piers Vitebsky

Scott Polar Research Institute, University of Cambridge, Lensfield Road, Cambridge CB2 1ER (pv100@cam.ac.uk)

Anatoly Alekseyev

Faculty of History, M.K. Ammosov North-Eastern Federal University, 58 Belinsky Street, 677980 Yakutsk, Russia

Received February 2014

ABSTRACT. The reindeer (Rangifer tarandus) is the mainstay of most of the indigenous cultures and economies of the Eurasian north. Yet much of the literature ignores indigenous perspectives in favour of ecological perspectives based on a resource-oriented model. While acknowledging the role of scientific writing on reindeer, here we explore the meaning of reindeer economies that are also reindeer cultures. We show how reindeer can be endowed with a personhood which parallels that of humans, leading to a working partnership which encompasses both ecological and spiritual dimensions. Even when reindeer herders qualify in veterinary science, this does not wipe out their indigenous understanding of the nature of the reindeer. We relate this to the physical, social and moral demands of life in the taiga.

'Quadruped. Graminivorous. Forty teeth, namely twenty-four grinders, four eye-teeth, and twelve incisive. Sheds coat in the spring; in marshy countries, sheds hoofs too. Hoofs hard, but requiring to be shod with iron.

Age known by marks in mouth.' ...

'Now girl number twenty,' said Mr Gradgrind, 'you know what a horse is.'

Charles Dickens, Hard Times, chapter 2

\section{Introduction}

The domesticated reindeer (Rangifer tarandus) is the mainstay of the economy of most of the indigenous peoples of the Eurasian north, most spectacularly of the Nenets, Chukchi, Eveny and Evenki in the Russian north and (on the symbolic level if not in the number of employees) of the Sámi (Saami) in Fennoscandia. Numbers of reindeer fluctuate considerably over time (Krupnik 1993) owing to disease, climatic and above all political factors (Rees and others 2008). For example, the collapse of the Soviet Union halved the number of domestic reindeer in Russia in just ten years from around 2,400,000 in 1990 to 1,200,000 in 2000 (Jernsletten and Klokov 2002: 28). Reliable figures for today are hard to calculate (Horstkotte and others no date) and have risen or fallen in each region for specific local reasons, but the overall total is unlikely to be higher than it was in 2000.

This article will ask what a reindeer is, as a creature which stands between contrasting scientific, indigenous, political and popular perspectives. The reindeer not only pulls Santa's luggage but also has to carry projections from diverse human worldviews. Perhaps most obviously it represents a pride in northernness, and in this sense it is silhouetted on the coat of arms of various Arctic municipalities (for example Lovozero, Naryan-Mar, Magadan), often containing large populations of white settlers who have never seen a reindeer in real life. It thus becomes a symbol almost like a unicorn, an animal that does not need to exist in order to have meaning. Similarly, Santa's reindeer originated as the fantasy of a Professor of Classics in New York who wrote the poem 'The night before Christmas' in the 1820s. He too, like his readers, had probably never seen a reindeer. Ingold, whose edited volume What is an animal? (1994) partly inspired the title of the present article, has encountered many. He writes that its 'large eyes confront the observer with an expression of vacant melancholy' (1980: 19). One of the authors of the present article writes that its eyes are 'compelling... huge, soulful, and capable of engaging one with an intense gaze' (Vitebsky 2005: 58). As modern British anthropologists we have humanised, even psychologised, the animal in front of us. Yet our interpretations of its 'personality' already vary between 'vacant' and 'intense.' What more does a reindeer become if you depend on it for your living, and even your life?

The origin of reindeer domestication is unknown, but many scholars agree that this probably took place in southern Siberia 2-3,000 years ago either in the Sayan mountains or around Lake Baikal, and probably by the ancestors of today's Evenki and Eveny peoples (Vasil'yevich and Levin 1951; Vainshtein 1980; Pomishin 1990). It seems likely that the species was first domesticated in small numbers to carry humans and their 
luggage in order to hunt animals, including wild reindeer (sledges came much later). It was probably the ability to ride on reindeer that opened up much of north Asia to human habitation, and it allowed the Eveny and Evenki to become among the most widely spread-out indigenous peoples anywhere in the world, transferring their discovery of reindeer domestication to other neighbouring groups. The huge herds of modern times arose only with Russian colonialism from the seventeenth century onwards (Krupnik 1993) and even more in the twentieth century with a Soviet agricultural regime based on production targets. A similar development occurred in Fennoscandia from the expansion of the Swedish empire and the emergence of the modern Scandinavian states. All of this was a marked shift away from an emphasis on transport, and amounted to an industrialisation of reindeer herding which turned it into a kind of extensive meat ranching. Throughout the indigenous Eurasian north today reindeer are used for pulling sledges, and in many areas they are saddled and ridden (though not in Fennoscandiavia where the breeds are too small). In some parts of Siberia they are also milked (Fondahl 1989). Almost everywhere there has grown up a large general herd of animals which exist only for breeding or (mostly) to be killed and eaten. Despite many regional variations and the post-Soviet dismantling or restructuring of state farms, the basic structure of the herd almost everywhere in the Eurasian north remains this mass herd, with small numbers of animals being specially selected and trained for riding, sledging or milking according to local usage.

\section{The reindeer as an object of knowledge and management}

The academic and scientific literature dwells on the idea of the reindeer as a denizen of an extreme environment with an extraordinary metabolism, and as a herd animal migrating annually over huge distances, often hundreds of miles, following seasonal changes in vegetation. Both wild and domestic reindeer show the same instinct for aggregating in herds, and for migrating in a repetitive cycle along the same routes for years or centuries at a time. Strong leaders trample paths through the snow for their followers, and individuals in a packed herd are relatively immune to wolves, which tend to attack only isolated stragglers.

This much is 'objectively' true whatever your worldview, but it can rapidly lead to a narrow scientific and policy discourse which is about managing, confining and directing the animals (for criticism of this managerial approach in Sweden, Finland and Norway respectively, see for example Beach 1981; Mazzullo 2010; Reinert 2008). Indigenous peoples also manage and direct reindeer, and have done so long before the modern state became heavily involved (Anderson 2004). But as we shall see, to them this can mean something very different, and the scientific-official and indigenous discourses often fail to engage each other even when they co-exist in the mind and the life of the same person. This is particularly so when the indigenous perspective includes anything which from the scientific perspective might be called 'spiritual' or 'religious.'

The species Rangifer was never domesticated in the American north, where it exists only in the wild and is called caribou. Here there are no domestic reindeer except a few which were introduced to Alaska in the 1890s, so the scientific talk about caribou is not of herding but of wildlife management. This is supported by a literature which in recent years has centred on concepts such as 'adaptive capacity,' 'vulnerability' and 'resilience'. Despite much talk of 'co-management' (for example Padilla and Kofinas 2014) there is generally a large gulf between the idioms of wildlife managers and indigenous caribou hunters (Ferguson and others 1998), in which the idiom of the former generally prevails. This matches a longstanding tendency in Arctic research and policy to sideline indigenous knowledge in favour of 'scientific' knowledge, and indigenous agendas in favour of outside 'southern' agendas.

This article focuses on Russia, and particularly on the Russian northeast. In Russia, scientific and indigenous discourses can potentially shade into each other more readily than in North America, since the presence of domesticated animals offers a wider range of situations in which these dicourses can meet. Both wild and domesticated reindeer show many of the same behavioural characteristics, including the need to migrate along similar routes (Baskin 1970; Syroechkovsky 1995; Syrovatsky 2000). So similar are their needs (with some minor qualifications) that they compete directly for pasture and there is a general inverse correlation between them: domestic reindeer increase at the expense of wild reindeer, and vice versa (Klein 1980). Some of the same managerial concepts used in managing wild reindeer, such as 'carrying capacity,' fit equally well with domestic reindeer herds, although in both cases, this easily shades into judgements about 'overgrazing,' without the recognition that this is an ideological as much as a scientific concept. The prominent Arctic theme of climate change is also arguably less significant in Russia than in North America (Forbes and Stammler 2009). In our fieldwork experience, herders talk about climate variability rather than climate change. They see constant adaptation and fine-tuning as the whole point of their work, using their skills from day to day to take advantage of useful fluctuations in conditions and to cushion their animals from the effects of negative ones (for a similar point regarding Norway, see Weladji and Holand 2006; Tyler and others 2007).

Any serious study of reindeer herding shows that the influence of social and political change is vastly greater than that of climate change (Rees and others 2008; Forbes and Stammler 2009; Vitebsky 2005). The reindeer population is drastically and swiftly affected by a change in the law on land (Novikova 2003), the opening or closing of a school for herders' children, the payment or non-payment of wages to a dinner-lady who feeds the herders in a tent (Vitebsky 2010), or the provision or withdrawal of funding for a helicopter to shoot wolves. 
This is closely reflected in the discourses where the reindeer herders themselves participate. Thus while the articles in Rangifer, the only international scientific journal devoted to the species, are mostly biological or ecological, magazines written by and for local people such as Magadansky Olenevod (The Magadan Reindeer Herder, now renamed Novosti Olenevodstva, Reindeer Herding News), contain veterinary tips but also many critical articles on economics, policy and legislation. But even in Russia, where such a level of awareness about the herders themselves is easy to come by, scientists can still present a study of 'overgrazing' by domesticated reindeer on Yamal Peninsula as follows: 'The resilience of tundra ecosystems is limited... lemmings may reduce above-ground plant biomass by $50-70 \%$. At the same time... potassium, phosphorus and nitrogen [in the urine of lemmings] promotes vascular plant growth...' (Kryazhimskii and Danilov 2000: 107). But the vast, emptylooking bog of Yamal is actually a highly humanised landscape. It has the largest and most successful reindeer economy in modern times: where all other regions by any reckoning have lost numbers since 1990, Yamal alone has leapt from around 400,000 to over 600,000 domestic reindeer. The Nenets herders on Yamal were exceptionally quick to jump into the newly opened Korean market for young antlers as tonics and aphrodisiacs (Stammler 2011; Yudin 1993), and all of this has happened in long-running conflict with the development of one of the world's largest gas fields (Vitebsky 1990; Forbes and others 2009). But Kryazhimskii and Danilov's 'systemic' approach contains almost no recognition that grazing levels are determined by human lifestyles and policy decisions, and no indication at all of what the herders themselves may know about plants and how this knowledge may cause them to direct the herds.

In the early Soviet days, reindeer herders' own views were sometimes taken into account and attempts were made to integrate them into official planning, especially among the Komi in the European north, though this was also the area where the most intrusive techniques of modernisation were first tried out (Kertselli and Khudadov 1919; Kertselli 1931; Habeck 2005: 206-207). Soviet scientific management introduced measures such as shift regimes based on the fly-in fly-out model of industrial workers, long fences to direct migrations and prevent neighbouring herds from mixing, and indeed the very concept of the sedentary village instead of the nomadic tent (Slezkine 1994; Vitebsky 2005: 41-56, 183-195). Anderson (2000) identifies a sequence of historical phases during the twentieth century, some better some worse, but in the end mostly regarding indigenous ideas about reindeer as 'obstacles to the intensification of northern production' and the people themselves as 'passive recipients of knowledge and aid rather than active partners,' all amounting to an 'aggressive neglecting of local traditions' (Anderson 2000: 156, although Soviet veterinary science has been fairly respectful to indigenous experience of selective breeding, see Stammler 2005: 51-52).

When reindeer are forced to change their routes, they can prove very resistant and may keep reverting to old, familiar paths. Not only in the routes but also in the timing of each stage of migration, as reindeer and herders migrate together in synchrony, it is not so clear who leads whom (compare Beach and Stammler 2006; for a detailed account of the logistics and moods of migration, see Vitebsky 2005: 114-128). Many modern, managed migration routes turn out to be little different from earlier pre-Soviet routes which pre-date official management, and even to correspond to the ancient movements of wild herds. Previous migration routes were systematised by the Soviet regime to give maps of exclusive, non-overlapping territories occupied by separately defined herds, each with its own herders and separate system of accounting. Each herd was allocated a sequence of separate pastures to occupy in each season, and a map which precisely calculated the small number of reindeer-days which each tiny component parcel of land was supposed to be able to sustain. The establishment of the village and its accompanying farm amounted to a contract in which the Soviet state would provide veterinary care, administration and aviation in exchange for the production of meat. Among Eveny herders in the Verkhoyansk Mountains in the north of the Sakha Republic/Yakutia, the area studied most intensively by both authors of the present article, one state farm or its successor enterprise might contain several herds, each consisting of some 2,000 reindeer which range around some 70,000 hectares and are managed by six or seven herders who are fed by one dinner-lady.

The work of the herders is linked to a larger number of administrators, accountants and other workers in a central village. In order to become fully integrated in the Soviet economy, reindeer herders were supposed to resemble any state employee in any factory all over the Soviet Union, and reindeer herding became one of a range of jobs needed to sustain the settled village's infrastructure. The previous 'nomadism as a way of life' was considered primitive and was to be replaced by 'productive nomadism', in which the village held most of the population while the herders went out in shifts to look after the reindeer migrating around the landscape. This was a total reindeer economy, based on a vision of 'high modernism' (Scott 1999: 4) in which the ultimate value could only be the production of meat, along with other by-products of the reindeer's body like antlers and furs. It is also the system which, with many regional and individual variations, remains to this day, though now in a more or less market-oriented form which no longer guarantees the provision of veterinarians, aviation or any other helpful facilities.

\section{The reindeer as a creature one lives with}

How did people manage in the past without managers? They were in close contact with animals every day of their lives and had elaborate and subtle techniques for relating to them. Even the concept of indigenous 
knowledge' is inadequate for grasping this, since it was indeed a 'way of life,' and what counted was not 'knowledge' as a thing or commodity, but knowing and being knowledgeable as an orientation to the world (compare Vitebsky 1993). Reindeer are behaviourally very flexible, and each animal is influenced by the nature of its human interactions. Even in the mass herd, an experienced herder will know something of the character and medical history of every one of his animals. The more distinctive reindeer used for riding or milking have their own names and are even more directly moulded by this interaction, to a degree that makes Takakura (2010) prefer the term 'familiarity' to 'domestication' or 'tameness'. Northern languages have enormous numbers of specialised words for aspects of reindeer including morphology, movement and equipment $(1,500$ Eveny words are listed in Dutkin, no date). Many of these describe not just permanent features like shape or colour, but also character or passing moods, mostly in their relations with humans. There are separate terms for reindeer that are sly tricksters, that run in the wrong direction, that lead or follow, or that do or do not cooperate at certain moments. As with the question of who leads whom, this vocabulary acknowledges that humans are not fully in control, and that everything that happens between them is the result of a tussle, a compromise, or a willing collaboration, what Beach and Stammler (2006: 8) call 'symbiotic domesticity'. At the same time this humanises the reindeer, but not in the manner of anthropologists deciphering the reindeer's personality through its gaze, nor in the sentimental way that Santa's reindeer are made to smile and talk in cartoons and advertisements. It makes reindeer like humans, and as will be shown below it even makes humans like reindeer as they mirror each other in a symbiotic ecology of mood (Vitebsky 2005: 107).

The difference between the perceptions of the herders and of any other people involved in managing their reindeer begins at the most utilitarian level, even without touching on any spiritual or symbolic elements. The Soviet state farm's notion of management was geared towards economic maximisation through the production of commodities, as well as towards high birth and survival rates among reindeer calves. This vision was fuelled by an elaborate system of statistical reports, prizes, medals and public citations, all awarded for high productivity in terms that could be measured (Vitebsky 2005: 235-237). Though the prizes and medals have largely disappeared, the post-Soviet transition to a 'market economy' has done nothing to lessen this emphasis. The managers aim for a ratio of fifteen to eighteen breeding females to one breeding male. In response to these demands the herders hold back the best males for breeding and use the surplus males to provide the meat. But especially in this jagged mountainous region of the northeast where snowmobiles are difficult to obtain, maintain and use, they also select the best males for another essential purpose which does not show up on official statistics at all: to be castrated and trained to carry a saddle or pull a sledge. It is ironic that the original reason for domestication remains a vital function for the herders themselves, but cannot be included at all in the industrialised vision. From the herders' perpective, this meat which is so valued by the managers is the byproduct of a process of rejection: unneeded males, weak or injured animals, unsocial animals with a bad attitude. The reindeer which are slaughtered and earn their herders rewards and bonuses are the ones that are not good enough to keep.

We suggest that the key to this discrepancy is the tendency of managers and scientists alike to classify reindeer according to certain principles. Managers tend to have the most power in the situation but the least close familiarity with the reindeer. The herders understand this classification and use it part of the time, but they also classify reindeer in ways which see some reindeer as special or outstanding according to very different principles. The idea of a riding reindeer shades into areas which we might call 'sacred,' and indeed when speaking Russian the herders use this term (svyaschenny, derived from Orthodox Christianity and also used in Russian anthropology).

Sacred reindeer are found in old ethnographic sources among many indigenous peoples of the Russian north (Ksenofontov 1928: 37, 57; Kostikov 1930). The details and uses vary, but they seem always to have a protective or sacrificial function and are identified by special colours, whether white or with particular mottled or piebald markings. Our own fieldwork with the very oldest people among the Eveny has revealed a range of sacred reindeer, called in the Eveny language by specific terms. Ordinary reindeer too can become sacred when sacrificed to feed a guest, to please the spirit of wild animals for success in hunting, to smear a newborn baby with blood, to feed fresh warm blood to a sick person, to bless a new bride, or to divine the whereabouts of game animals by reading cracks that appear to form a map when its left shoulderblade is heated on the embers of a fire (Vitebsky 2005: 265-268).

Many of these sacred functions arise from the role of the riding deer as intimate companion of its rider, day in day out. Today as in the past, a herder's mount communicates by grunting and snorting (oroon nuuhokron); it can advise its rider about good or bad places to hunt, and also give advance warning of avalanches and other serious dangers. When its rider, man or woman, dies their favourite mount is sacrificed on their grave. It is a good sign if it dies easily and without a struggle, as this means that it is going willingly to carry its rider around the pastures and hunting grounds of the next world. Unlike the ordinary stabbing in the cerebellum to sever the spinal cord, this deer is strangled with a lasso so that it passes through into the next world undamaged and still 'alive.' Every bone is extracted from the flesh and meticulously counted, since if even the smallest bone is lost, the reindeer will be lame and the dead person immobilised. The meat is eaten on the spot in a funeral feast, 
while the bones are carefully gathered in a box and put with the antlers on a platform on top of a pole next to the grave. Sometimes the skin is suspended from a tree, uncannily preserving the animal's original shape 'with legs flopping down like an empty sack from which everything - meat, bones and soul - [has] been sucked out.' (Vitebsky 2005: 330; illustrated in Vitebsky 2001: 136). A suitable reindeer is sacrificed even for village administrators, accountants, teachers and boiler attendants. As Eveny, it seems they too will give up their sedentary jobs and be nomads in the next world.

In the past, a reindeer would carry its rider's soul as well as body even in life. During a new year ritual (actually in the 24-hour daylight of midsummer's day), each person would take part in a ritual of 'flying up to the sun' to receive a blessing for the year to come (Alekseyev 1993: 25-34). The rider would sit on his or her reindeer, pass anticlockwise round a bonfire (that is against the direction of the sun) symbolising the death of the old year, and then clockwise around a second fire to symbolise the birth of the new year. As the next stage of the ritual the person would act out a flight on reindeer-back up to the sun, into the realm of the creator-god Hövki in the sky. The prayers would include 'O spirit of the great sun... give us vigorous and swift reindeer... multiply our herds and their calves’ (Alekseyev 1993: 29).

Being intimate with a rider is the most basic way in which a reindeer can be special. This role is emphasised by the fact that some other reindeer are so special that they can not be ridden. Until recently the collective vitality or soul-force of the entire herd was concentrated into a specially selected grey or snow-white reindeer called edjok which lived all its life free and unharnessed amidst the main herd. Another extremely sacred reindeer was a snow-white animal called hebek or höbök which was consecrated to Hövki and was used for no other purpose than to carry a shaman's robe and drum wherever he or she travelled. This deer likewise was never harnessed, but walked around 'by itself.' When either of these animals died its body was placed on a tree platform 'half-way between the earth and the sky,' exactly as humans were placed until the 1930s when the hygienic new Soviet regime insisted on burial in the earth.

The most widespread sacred reindeer, which has persisted to this day, is the personal protecting reindeer called kujjai (Alekseyev 1993: 63-72; Vitebsky 2005: 278-281). Most people today still have their own kujjai (as from time to time have the authors of this article, as well as their families). The kujjai acts like an animal double: when you are threatened by serious danger, it places itself in front of you of its own free will and takes the blow. The kujjai must never be ridden, harnessed, tied up, beaten or eaten. It has special markings which vary according to region and even to the feelings of their individual human partners. It may have an unusual tuft of fur on the neck called tigok which is plucked and carried round in a little bag as a talisman, in effect a portable bit of the deer which is always with you. It can sometimes be recognised by its strange eyes which may be milky, 'hypnotic,' or 'like a shaman.' It is sometimes said that it is blind by day but can see at night, when its eyes glow with a special light of their own. In earlier literature and among our oldest informants, when a person was sick that person's kujjai would be brought to them in order to breathe on their chest, forehead and stomach, or sometimes directly on the affected part (compare Anon. 2012: 34; Okladnikov 1989: 84). When their kujjai dies, Eveny believe that it has absorbed the shock of a danger that might have killed its owner. The kujjai thus participates actively and knowingly in a relationship of reciprocal protection against danger: the human protects the deer from wolves and bears, while the deer protects its human protégé from falling off precipices or through weak ice. The sacredness and the predictive power of the kujjai are an extreme version of those of the riding deer. It has an intense symbiotic relationship with its owner and a superior awareness of dangers, and it exists to serve and protect that owner and to die knowingly on its owner's behalf.

It would take a much fuller analysis to do justice to the complexity of these sacred functions (Alekseyev no date). The point to note here is that domesticated reindeer can be endowed with a range of deep meanings which run along a spectrum from the materially fundamental lifegiving function of riding, to sacrifice as the heart of religion. Before the growth of mass herds perhaps every reindeer was special in one of these ways. These special reindeer bring together several key motifs which are fundamental to Eveny culture (and are matched by equivalent if different motifs in other indigenous cultures of the Russian north). Each of these motifs makes the special reindeer very similar to a human. Humans were buried up a tree, and so were special reindeer. Like humans, they were not eaten. And in the egalitarian pre-Soviet culture, before hierarchy was introduced by state farm directors, school principals and Party bosses, humans were supposed to be extremely autonomous agents, and outside the village it is still very apparent in the nomadic herders' tents that no one person is supposed to control another (Vitebsky 2005: 111-113). In the same way, a sacred reindeer is an autonomous agent rather than a captive, and should walk free and come and go of its own volition. Ordinary reindeer in the general herd are caught by lasso and dragged struggling to where the herder wants to place them. But riding deer are not tethered unless they are being saddled up for immediate use, and the kujjai, like the deer that carries the shaman's equipment, is never subjected to any control or constraint.

It is revealing to see which of these practices continue today, and to consider why. The survival, extinction or transformation of these customs is an outcome of various historical and political pressures, even when they are not the direct object of farm policy or of market forces. The shaman's equipment-carrying deer has disappeared because shamans, conspicuous by their dramatic trances and all-night drumming, were almost 
entirely killed off during the Soviet regime's war on religion (Suslov 1931; the current 'shamanic revival' is a movement among urban professionals rather than remote herders, Znamenski 2007). Large group rituals like the midsummer greeting of the sun were also conspicuous and so were easily suppressed. Even the remotest women are now taken by helicopter to hospital to give birth, so their babies are no longer smeared with fresh reindeer blood; and the edjok, guardian spirit of the herd, became obsolete when the herd was collectivised and turned into state property, and has not been revived under the present partial privatisation.

But certain practices do continue. Partly these address the greatest dilemmas, dangers and anxieties of living on this vast and perilous landscape: the need for hunting luck (deer which snort messages to their riders, or shoulderblades which reveal maps), the threat of fatal accidents (the riding deer which warns, or the kujjai which takes the blow), and life after death (the sacrifice on the grave). They also represent areas of life that lie beyond the control or protection of the authorities. Communists, agricultural scientists, map-makers, planners all bring new ways of knowing from outside, backed up by the power and the authorisation to downgrade or drive underground what the herders think they know about reindeer. The areas where the reindeer's sacredness persists are those, like kujjais and burials, which have been left with relatively little outside interference in the hands of the community (which here includes indigenous Communist Party bosses and now market entrepreneurs). These situations resemble other fields of intimate spiritual life which have similarly escaped state control and are similarly vigorous, such as receiving advance notice of visitors from the crackling of the fire, or about your destiny from dreams (Vitebsky 2005: 285-310).

\section{Conclusion}

Returning to our title, 'What is a reindeer?,' we see that it is an animal onto which all sorts of symbols and scenarios can be projected: a seasonal pressure to migrate which must be controlled by enormous fences, competition with urinating lemmings for plant biomass, the economics of meat marketing, climate change (or should this be variability?), Korean antler mafiosi, Santa's sledge, flights to the sun, nomadism which continues beyond the grave, the kujjai bodyguard that sacrifices itself... Herders today live with a mixture of any or all of these, and with no sense of contradiction. The herder who becomes an indigenous scholar may equally write about the logic of spirits or the botany of grazing (Alekseyev 1993; 2006). A young herder on a veterinary course may be given a textbook which includes 'sections on reindeer anatomy and physiology, breeding and pedigree work, nutrition and rational use of pasture, organisation of production, foundations of veterinary science, layout of social and industrial buildings, use of mechanised transport...' (from the blurb to Borozdin and others 1990). An indigenous vet or entrepreneur may study Vladimirov and others 2005, which according to its blurb combines chapters on 'the morphofunctional significance of the reindeer thymus in ontogenesis [and] experimental data on obtaining T-activin from the thymus' and 'theoretical foundations of waste-free technology in the extreme conditions of the Far North' with a guide to establishing a family reindeer enterprise under the market economy.

The same person who studies these textbooks may also have a kujjai and sacrifice his parents' riding deer on their graves. Maybe he will also believe in chakras and cosmic consciousness, and look out for extraterrestrial visitors in the forest. Here, the herders follow a blend which is very typical of Russian culture at both popular and elite levels, where science is made mystical and mysticism is rationalised in scientific terms. Indigenous herders read Russian books and popular magazines, but their own spirituality is ultimately different from Russian science fiction or New Age thinking because it is not rooted in the armchair. Indigenous spirituality also exposes the limitations of a utilitarian model in which the entire landscape is turned into nothing more than a gigantic open-air meat factory. Not one of these special reindeer roles has to do with the animal's meat as such, even when they involve prayers to multiply the herd or when a riding mount is eaten at the graveside. Nor do they have to do directly with any other economic idiom of cash or exchange, such as productivity of fur or antlers. Harvesting, of any commodity, is not the point. The values involved are intense, but they are cosmological and have rather to do with deeper conceptions of human wellbeing. The reindeer is the medium for the enactment and realisation of these values. All special reindeer roles seem to be related to riding, sacredness, or a combination of these which sometimes leads to a privileged exemption from the basic function of being ridden. Indeed, all these emerge as part of the same complex: they go back to transport as the original driver for domestication, and behind this perhaps to an underlying sense of sacredness and sacrifice (compare Willerslev and others in press). What unites all of these roles is a relationship of intimacy, identity and fragile cooperation between reindeer and human. No wonder these roles are not valorised in the bureaucratic state farm or the more recent market economy, any more than they would find a place in the cosmology of the wildlife management professional. But they are an integral part of the herder's skill, a hidden world of specialist knowledge which enables the herder to function in the more public official idiom of productivity statistics.

How does the reindeer manage to fill so many necessary roles? While other animals such as horses or dogs can form individual links with humans, reindeer behaviour allows them both to be a special human companion and to run around with the herd. Takakura (2010: 21-42) argues that while pastoralists in arid zones achieve diversification by sharing out roles between a range of species such as sheep, goats and cattle, reindeer herders in the Arctic achieve what he calls a 'diversification of roles' within their single available species. Stammler 
(2010), in the same volume, gives an extra twist to this argument by showing how a range of wild animals, and even fish, can significantly broaden the range of significant species in an overtly reindeer economy. We would add that creating contrasting categories of reindeer within the same herd helps to separate out different strands of the idea of a reindeer, so that different individual animals can be habituated to play each of these complementary roles.

The common disposal by tree burial and the common ideal of autonomous agency suggest that an equivalence with humans may be the original core significance of the domesticated reindeer: with an additional touch of magic since reindeer can also possess extra powers and knowledge, like the ability to bless or to perceive invisible dangers, which are unavailable to their human partners (unless these are shamans). It is debateable whether it is in Fennoscandia or the Soviet Union that managerialism and scientism have gone further in making reindeer less like humans and more like the entities studied by biologists. Reinert (2008), speaking of Norway, reveals the bleakness of capitalist high modernism when he uses concepts of 'bare life' and 'necroavailability' to liken reindeer slaughterhouses to human death camps (by contrast, Paine 2009 writes of Sámi herders a generation earlier who attacked each other by hurting or killing each other's personal reindeer - an identification similar to the kujjai even if without the kujjai's awareness). The Soviet version of high modernism did literally place Gulag camps across the territory of reindeer herders (Vitebsky 2005: 212-230; Ulturgasheva 2012: 131-153). But more than anywhere else in the north the reindeer-herding societies of Russia have at the same time preserved traces of a very archaic pattern of equivalence between reindeer and humans - now with a particularly Soviet tone. The behavioural patterns of different species open up different routes to sacredness. For reindeer, their strong herd instinct gives them a sociality which makes them a good symbol or analogue for human society. Like the human population, the mass herd under Soviet management swelled to form a lumpen-proletariat of lower-class reindeer with a low potential for human-like consciousness. Like workers, these animals were useful and necessary (for breeding, meat, and wolf-fodder), but like workers too they were expendable. Indeed, they were bred to be eaten. Above them, like the members of the Communist Party, rose an elite of the riding deer and of the other sacred deer which could never be ridden, let alone eaten (and unlike those atheist Party members, this elite is conceived in spiritual terms). We see here a continuity of the original impulse towards domestication long before any reindeer were kept for their meat. In that early form of domestication when the number of domestic reindeer was small, we suspect that they were all more or less sacred, and that this sacredness was based on the two roles that were available for them: transport and sacrifice, or a blend of the two.

Traditional, Soviet or post-Soviet: when the relationship between Homo sapiens and Rangifer tarandus focuses on their similarity or equivalence, it remains a long way either from Santa or from ecological models of herd management, biological studies of metabolism, or economistic goals of mass productivity. But such notions of similarity can offer a reflection of human society, and even a political commentary (herders in Russia are very good at satire, and often ironically name their reindeer after public figures). Since the end of the state farm in the 1990s, herd structures have become more uncertain and unbalanced. Perhaps in our future research we will be able to interpret this latest development as a post-modern reflection of the destabilised society of their post-socialist human minders.

\section{Acknowledgements}

We are grateful to Hugh Beach, Otto Habeck and Florian Stammler for their helpful and knowledgeable comments. Piers Vitebsky would also like to acknowledge Anatoly Alekseyev's generosity as an indigenous informant long before he became an anthropologist and colleague.

\section{References}

Alekseyev, A.A. 1993. Zabyty mir predkov [Forgotten world of the ancestors]. Yakutsk: Sitim.

Alekseyev, A.A. 2006. Tekhnologiya soderzhaniya i produktivnost' severnykh oleney v gorno-taezhnoy zone Respubliki Sakha (Yakutia) [The technology of upkeep and productivity of reindeer in the mountain-forest zone of the Sakha Republic (Yakutia)]. Novosibirsk: Nauka.

Alekseyev, A.A. no date. Obychai i obraydy evenov, svyazannye s olenem [Customs and rituals of the Eveny associated with reindeer], typescript. (Available in the library of the Scott Polar Research Institute, Cambridge)

Anderson, D. 2000. Rangifer and human interests. Rangifer 20(2-3): 153-174.

Anderson, D. 2004. Reindeer, caribou and 'fairy stories' of state power. In: Anderson, D. and M. Nuttall (editors). Cultivating Arctic landscapes: knowing and managing animals in the circumpolar north, New York and Oxford: Berghahn: 1-16.

Anon. (Anonymous). 2012. Anabar - vechnye tsennosti. [Anabar - eternal values]. Krasnoyarsk: Inspaer.

Baskin, L. 1970. Severny olen': ekologiya i povedenie [Reindeer: ecology and behaviour]. Moscow: Nauka.

Beach, H. 1981. Reindeer-herd management in transition: the case of Tuorpon Saameby in Northern Sweden. Uppsala: Acta Universitatis Upsaliensis.

Beach, H. and F. Stammler, F. (editors). 2006. People and reindeer on the move. Nomadic Peoples, 10 (special issue).

Borozdin, E.K., V.A. Zabrodin and A.S. Bagin. 1990. Severnoe olenevodstvo [Northern reindeer herding]. Leningrad: Agropromizdat.

Dutkin, Kh. I. no date. Terminy olenevodstva $v$ evenskom yazyke [Reindeer herding terms in the Eveny language]. Yalutsk: Yakutsky Filial SO AN SSSR

Ferguson, M.A.D., R.G. Williamson and F. Messier. 1998. Inuit knowledge of long-term changes in a population of Arctic tundra caribou. Arctic 51: 201-219. 
Fondahl, G. 1989. Reindeer dairying in the Soviet Union, Polar Record 25 (155): 285-294.

Forbes, B.C. and F. Stammler. 2009. Arctic climate change discourse: the contrasting politics of research agendas in the west and Russia. Polar Research 28: 28-42.

Forbes, B.C., F. Stammler, T. Kumpula, N. Meschtyb, A. Pajunen and E. Kaarlejärvi. 2009. High resilience in the Yamal-Nenets social-ecological system, west Siberian Arctic, Russia. Proceedings of the National Academy of Sciences 106(52): 2204122048.

Habeck, J.O. 2005. What it means to be a herdsman: the practice and image of reindeer husbandry among the Komi of Northern Russia. Münster: LIT Verlag.

Horstkotte, T., E. Kaarlejärvi, F. Stammler, J. Moen, B. Forbes, A. Yuzhakov and J. Oloffson. No date. Are caribou and reindeer declining? Comments on 'Global declines of caribou and reindeer' by L V Vors and M S Boyce. Unpublished manuscript. (Available in the libraries of the Scott Polar Research Institute, Cambridge and the Arctic Centre, Rovaniemi, Finland)

Ingold, T. 1980. Hunters, pastoralists and ranchers. Cambridge: Cambridge University Press.

Ingold, T. (editor). 1994. What is an animal? London and New York: Routledge.

Jernsletten, J.L. and K. Klokov. 2002. Sustainable reindeer husbandry. Tromsø: Centre for Saami Studies.

Kertselli, S. 1931. Olenevodstvo SSSR i ego perspektivy [Reindeer herding of the USSR and its prospects]. Sovetskaya Azia1,2: 27-34.

Kertselli, S., and V. Khudadov. 1919. Olenevodstvo [Reindeer herding]. Moscow: Izdatel'stvo Narodnogo Komissariata Zemledeliya.

Klein, D.R. 1980. Conflicts between domestic reindeer and their wild counterparts: a review of Eurasian and North American experience. Arctic 33: 739-756.

Kostikov, L. 1930. Bogovy oleni v religioznykh verovaniyakh Khasovo [Sacred reindeer in the religious beliefs of Khasovo]. Etnografiya 1930(1-2): 115-133.

Krupnik, I.I. 1993. Arctic adaptations: native whalers and reindeer herders of northern Eurasia. Hanover and London: University Press of New England

Kryazhimskii, F.V. and A.N. Danilov. 2000. Reindeer in tundra ecosystems: the challenge of understanding system complexity. Polar Research 19(1) (Special issue. Proceedings of the human role in reindeer/caribou systems workshop): 107-110.

Ksenofontov. G.V. 1928. Legendy i rasskazy o shamanakh u Yakutov, Buryat $i$ Tungusov [Legends and stories about shamans among the Yakut, Buryat and Tungus]. Irkutsk: Izdanie Yakutskoy Sektsii VSORGO.

Mazzullo, N. 2010. More than meat on the hoof. In: Stammler,F. and H. Takakura (editors), Good to eat, good to live with: nomads and animals in northern Eurasia and Africa. Sendai, Japan: Tohoku University, Centre for Northeast Asia Studies: 215-243.

Novikova, N. (editor). 2004. Olen' vsegda prav: issledovaniya po yuridicheskoy antropologii [The reindeer is always right: studies in legal anthropology]. Moscow: Strategiya.

Okladnikov, A.P. 1989. Olen'- zolotyye roga [The deer - golden antlers]. Khabarovsk: Khabarovskoe Knizhnoe Izdatel'stvo

Padilla, E. and G.P. Kofinas. 2014. 'Letting the leaders pass': barriers to using traditional ecological knowledge in comanagement as the basis of formal hunting regulations. Ecology and Society, 19 (2): item 7. URL: http://www.ecologyandsociety.org/vol19/iss2/art7/. (accessed 14 February 2014)

Paine, R. 2009. Camps of the Tundra: politics through reindeer among Saami pastoralists. Oslo: Novus.

Pomishin, S.B. 1990. Proiskhozhdeniya olenevodstva $i$ domestikatsiya severnogo olenya [The origin of reindeer herdering and the domestication of the reindeer]. Moscow: Nauka.

Rees, W.G., F.M. Stammler, F.S. Danks and P. Vitebsky. 2008. Vulnerability of European reindeer husbandry to global change. Climatic Change 87: 199-217.

Reinert, H. 2008. The corral and the slaughterhouse: knowledge, tradition and the modernization of indigenous reindeer slaughtering practice in the Norwegian Arctic. Unpublished PhD dissertation. Cambridge: Cambridge University, Scott Polar Research Institute (available on academia.edu).

Scott, J. 1999. Seeing like a state: how certain schemes to improve the human condition have failed. New Haven: Yale University Press.

Slezkine, Y. 1996. Arctic mirrors: Russia and the small peoples of the North. Ithaca: Cornell University Press.

Stammler, F. 2005. Reindeer nomads meet the market: culture, property and globalization at the 'End of the Land'. Berlin: Lit.

Stammler, F. 2010. Animal diversity and its social significance among Arctic pastoralists. In: Stammler, F. and H. Takakura (editors). Good to eat, good to live with: nomads and animals in northern Eurasia and Africa. Sendai, Japan: Tohoku University, Centre for Northeast Asia Studies: 215-243.

Stammler, F. 2011. Capitalism in the tundra or tundra in capitalism? Specific purpose money from herders, antlers and traders in Yamal, West Siberia. In: Gertel, J. and R. Le Heron. Economic spaces of pastoral production and commodity systems: markets and livelihoods. London: Ashgate: 231-246.

Suslov, I.M. 1931. Shamanstvo i bor'ba s nim [Shamanism and the struggle with it]. Sovetskiy Sever 1931: 89-152.

Syroechkovsky, E.E. 1995. Wild reindeer. Washington DC: Smithsonian Institution.

Syrovatskiy, D.I. 2000. Organizatsiya i ekonomika olenevodcheskogo proizvodstva. [The organisation and economics of reindeer production]. Yakutsk.

Takakura, H. 2010. Arctic pastoralism in a subsistence continuum: a strategy for differentiating familiarity with animals. In: Stammler, F. and H. Takakura (editors). Good to eat, good to live with: nomads and animals in northern Eurasia and Africa. Sendai, Japan: Tohoku University, Centre for Northeast Asia Studies: 21-42.

Tyler, N.J.C., J.M. Turi and M.A. Sundset. 2007. Saami reindeer pastoralism under climate change: applying a generalized framework for vulnerability studies to a sub-Arctic social-ecological system. Global Environmental Change 17: 191-206

Ulturgasheva, O. 2012. Narrating the future in Siberia: childhood, adolescence and autobiography among the Eveny. Oxford and New York: Berghahn.

Vainshtein, S. I. 1980. Nomads of south Siberia: the pastoral economies of Tuva. Cambridge: Cambridge University Press.

Vasil'yevich, G. M. and M.G. Levin. 1951. Tipy olenevodstva i ikh proiskhozhdeniya [Types of reindeer herding and their origins, Sovetskaya Etnografiya (1): 63-87.

Vitebsky, P. 1990. Gas, environmentalism and native anxieties in the Soviet Arctic: the case of Yamal Peninsula. Polar Record 26(156): 19-26. 
Vitebsky, P. 1993. Is death the same everywhere? Contexts of knowing and doubting. In: Hobart, M. (editor). An anthropological critique of development: the growth of ignorance. London: Routledge: 100-115.

Vitebsky, P. 2001. Shamanism: voyages of the soul, trance, ecstasy and healing from Siberia to the Amazon. Norman: Oklahoma University Press.

Vitebsky, P. 2005. Reindeer people: living with animals and spirits in Siberia. Boston: Houghton Mifflin and London: HarperCollins.

Vitebsky, P. 2010. From materfamilias to dinner-lady: the administrative destruction of the reindeer herder's family life. Anthropology of East Europe Review 28(2): 38-50.

Vladimirov, L.N., I.S. Reshetnikov and V.A. Robbek. 2005. Nauchnyye aspekty vozrozhdeniya severnogo olenevodstva [Scientific aspects of the revival of northern reindeer herding]. Yakutsk: Ministry of Agriculture (and many other organisations).

Weladji, R.B. and O. Holand. 2006. Influences of large-scale climatic variability on reindeer population dynamics: implications for reindeer husbandry in Norway. Climate Research 32: 119-127.

Willerslev, R., P. Vitebsky and A.A. Alekseyev. in press. Sacrifice as the ideal hunt: a cosmological explanation for the origin of reindeer domestication. Journal of the Royal Anthropological Institute.

Yudin, A.M. 1993. Panty i antlery: roga kak lekarstvennoe syr'ye [Velvet and dry antlers: horn as medicinal material]. Novosibirsk: Nauka.

Znamenski, A.A. 2007. The beauty of the primitive: shamanism and the western imagination. Oxford: University Press. 